\title{
Isoflavones in Processed Soybean Products from Ecuador
}

\author{
Maria Inés Genovese ${ }^{1 *}$, Jorge Davila ${ }^{2}$ and Franco M. Lajolo ${ }^{1}$ \\ ${ }^{1}$ Departamento de Alimentos e Nutrição Experimental; Universidade de São Paulo; Av. Prof. Lineu Prestes, 580, \\ Bloco 14; genovese@usp.br; fmlajolo@usp.br; 05508-900; São Paulo - SP - Brasil. ${ }^{2}$ Departamento de Ciencia de \\ Alimentos y Biotecnologia; Universidad Politécnica Nacional; Quito - Ecuador
}

\begin{abstract}
Soy products produced in Ecuador, with a local developed and cultivated soybean variety (INIAP 306), were analysed for isoflavone content and profile. The products presented high total isoflavone contents, varying from 53 to $106 \mathrm{mg} / 100 \mathrm{~g}$ (wet basis, expressed as aglycones), the lowest content being for okara and the highest for the low fat soybean flour obtained by extrusion cooking of the seeds at the field moisture. Soy nuts showed the same content of isoflavones than the seeds, but with lower amounts of malonylglycosides and higher of the deesterified $\beta$ glycosides. The malonylglycosides were the predominant form of the isoflavones in the flours, and the $\beta$-glycosides in soymilk and textured soy protein. Genistein derivatives were the compounds present in the highest proportions in all the products analysed.
\end{abstract}

Key words: Ecuadorian soybean products, isoflavone content, isoflavone profile

\section{INTRODUCTION}

The consumption of soybeans has been associated to reduced risks of several chronic diseases such as coronary heart disease, osteoporosis, breast and prostate cancer. The main soy components related to these effects are the protein and the isoflavones (Adlercreutz and Mazur, 1997). Soybean contains three types of isoflavones, in four chemical forms: the aglycones daidzein, genistein, and glycitein; the $\beta$-glycosides daidzin, genistin, and glycitin; the acetyl- $\beta$-glycosides 6 "-O-acetyl- $\beta$-daidzin, 6 "-Oacetyl- $\beta$-genistin, 6 "-O-acetyl- $\beta$-glycitin; and the malonyl- $\beta$-glycosides 6"-O-malonyl- $\beta$-daidzin, $6 "-$ O-malonyl- $\beta$-genistin, and 6 "-O-malonyl- $\beta$ glycitin (Friedman and Brandon, 2001).

The importance of soy products is that they represent a way of incorporating isoflavones in the diet of populations that are not used to the consumption of the grains, such as the Ecuadorian. Soy flours, as an example, can be used in the preparation of bread high in phytoestrogens, whose daily consumption has been recently shown to favourably influence PSA (prostate-specific antigen) levels in men diagnosed with prostate cancer after just one month (Dalais et al., 2004). Soy protein products may be used as ingredients in meat products, breads, beverages, soups and other foods due to the physicochemical properties of soy proteins which help conferring texture and other important properties such as water retention and gelification. Soy milk can be used to elaborate flavored soymilk, yogurt, ice cream and tofu, and soy-nuts can be consumed as snacks and granola ingredients.

The objectives of this work were to determine the content and profile of isoflavones present in soy products produced in Ecuador, using a local developed and cultivated soybean variety (INIAP

${ }^{*}$ Author for correspondence 
306), in order to identify potential isoflavone sources.

\section{MATERIALS AND METHODS}

\begin{abstract}
Materials
Soybeans used in the production of the derivatives were from the variety INIAP 306 developed and cultivated in Ecuador. All the products were obtained at the Escuela Politécnica Nacional (Quito, Ecuador), according to the following procedures:
\end{abstract}

\section{Raw whole and dehulled soybean flours}

The seeds were first fractured in a Rietz disintegrator model RP-8-K115 (Rietz Manufacturing Co., Santa Rosa, USA) and after that milled in an Alpine mill, type $160 \mathrm{UPZ}, \mathrm{N}^{\circ}$ 3644.1 (Alpine Aktiengesellschaft and Co., Augsburg, Germany) at $18000 \mathrm{rpm}$ for the obtention of the raw whole soybean flour. The raw dehulled soybean flour was obtained in the same way, except for the previous dehulling of the seeds in a dehuller-classifier Bowermeister serial BR (Muehlenbau GmbH, Hamburg, Germany).

\section{Low fat soybean flour}

This flour was obtained based on extrusion cooking of soybeans at field moisture content, followed immediately by continuous expelling. Extrusion was carried out in a Bonnot Model 2 single-screw extruder (Bonnot Co., Kent, USA). The average residence time of material within the extruder barrel was approximately 30 seconds, with a screw speed of $143 \mathrm{rpm}$ and discharge temperature of $124{ }^{\circ} \mathrm{C}$. The material was cooled and milled in a Schutte-Buffalo hammer mill Model 38 (Schutte Pulverizer Co., Inc., New York, USA).

\section{Soy-nuts}

The production of soy-nuts was made after blanching soy cotyledons by dropping them directly into boiling water ( $100 \mathrm{~g}$ of soybeans $/ 500$ $\mathrm{ml}$ water) containing $0.05 \%$ sodium bicarbonate, for 10 minutes. After drainage of the water, cotyledons were spread on paper towel to remove excess water and shallow fried in soybean oil until brown and crispy. After removal of the excess of oil, powdered salt was sprinkled to taste.

\section{Soymilk}

For the production of soy milk, dehulled soybeans were first blanched for $5 \mathrm{~min}$ in water containing $0.05 \%$ sodium bicarbonate $(1: 5 \mathrm{w} / \mathrm{v})$. After discarding blanching water, soybeans were rinsed with hot water, drained, and ground with hot water with a Rietz disintegrator. The slurry was then filtered through a fine mesh sack to separate soymilk from the insoluble residue (okara), and the soymilk was cooked for $20 \mathrm{~min}$ at $85-88{ }^{\circ} \mathrm{C}$. Pasteurised soymilk was homogenised and freezedried for posterior analysis.

\section{Textured soy protein}

Textured soy protein was prepared after hydrating the low fat soybean flour in alkaline water for one hour. The material obtained (20-24\% moisture) was extruded using a Brabender Do-Corder extruder (Duisburg, Germany), with screw speed of $110 \mathrm{rpm}$, and temperature profile: $\mathrm{T}_{1}=80^{\circ} \mathrm{C}$, $\mathrm{T}_{2}=120{ }^{\circ} \mathrm{C}$ and $\mathrm{T}_{3}=200{ }^{\circ} \mathrm{C}$. Extruded samples were dried in a forced circulation air dryer (Proctor and Schwartz, Inc., Philadelphia, USA).

\section{Methods}

\section{Proximate composition}

Proximate composition was determined according to the AOAC (1995) methods.

\section{Isoflavone Extraction}

Soy samples, when necessary, were previously ground in a mill Janke and Kunkel A-10 (Wilmington, U.S.A.) under refrigeration until the sample passed through a $0.25 \mathrm{~mm}$ sieve. Powdered samples $(1 \mathrm{~g})$ were extracted with $80 \%$ aqueous methanol $(1: 20 \mathrm{w} / \mathrm{v})$ under agitation for $2 \mathrm{~h}$ at $4{ }^{\circ} \mathrm{C}$ (Genovese and Lajolo, 2001). The extracts were filtered through Whatman $n^{\circ} 6$ filter paper and concentrated until methanol elimination on a rotatory evaporator (Rotavapor® RE 120 - Büchi, Flawil, Sweden) at $\leq 40{ }^{\circ} \mathrm{C}$. The volume $(\sim 2 \mathrm{ml})$ was then adjusted to $5 \mathrm{ml}$ with HPLC grade methanol (final methanol concentration of $80 \%$ ). Aliquots of the samples were filtered through a $0.22-\mu \mathrm{m}$ PTFE filter unit [poly (tetrafluoroethylene), Millipore Ltd., Bedford, U.S.A.] and analysed by HPLC. The extractions were made in triplicate.

\section{HPLC Quantitation of Isoflavones}

Isoflavone separation and quantitation was performed according to Song et al. (1998) with a 
C18 NovaPak (30 cm x $4.6 \mathrm{~mm}$ id) column (Waters, Milford, U.S.A.) and a Hewlett Packard 1100 system equipped with a diode array detector and the software ChemStation (Palo Alto, U.S.A.). Identification was made based on the spectra and retention time, and quantitation based on external calibration. Concentrations of malonyl and acetylisoflavones were calculated using standard curves for the respective $\beta$-glycosides, adjusting for differences in molecular weight. Total isoflavone contents were expressed as $\mathrm{mg}$ of aglycone/100 g of sample fresh weight (FW), after normalisation of individual isoflavones to account for differences in molecular weight between glycoside derivatives. The mass of each isoflavone form ( $\beta$-glycoside, malonylglycoside and acetylglycoside) was multiplied by the ratio of its aglycone molecular weight to the molecular weight of the individual form before summing.

Table 1 - Proximate composition (\%) of INIAP 306 soybeans and a partially defatted soybean flour obtained by extrusion.

\begin{tabular}{lcc}
\multicolumn{1}{c|}{$\%$} & INIAP 306 soybeans & Low fat soybean flour \\
\hline Moisture & $11.0 \pm 0.4$ & $4.9 \pm 0.3$ \\
Protein & $35.0 \pm 1.0$ & $45.6 \pm 0.8$ \\
Fat & $21.2 \pm 0.2$ & $9.6 \pm 0.2$ \\
Crude fiber & $6.6 \pm 0.2$ & $0.25 \pm 0.01$ \\
Total Carbohydrates* & 28.1 & 33.7 \\
Ash & $4.7 \pm 0.1$ & $6.2 \pm 0.1$ \\
\hline
\end{tabular}

*by difference.

Table 2 - Total isoflavone content of soy products (mg/100 g FW) produced with INIAP 306 soybeans from Ecuador, expressed as aglycones.

\begin{tabular}{l|c|c|c}
\hline \multicolumn{1}{c|}{ Soy product } & $\begin{array}{c}\text { Lipid content } \\
(\boldsymbol{\%})\end{array}$ & $\begin{array}{c}\text { Moisture } \\
(\mathbf{\%})\end{array}$ & $\begin{array}{c}\text { Total isoflavones } \\
(\mathbf{m g} / \mathbf{1 0 0} \mathbf{g ~ F W})\end{array}$ \\
\hline Raw whole soybean flour & $20.5 \pm 0.2^{\mathrm{a}}$ & $6.8 \pm 0.2^{\mathrm{a}}$ & $67.8 \pm 1.7^{\mathrm{a}}$ \\
Raw dehulled soybean flour & $23.8 \pm 0.3^{\mathrm{b}}$ & $6.2 \pm 0.2^{\mathrm{bc}}$ & $75.3 \pm 2.4^{\mathrm{b}}$ \\
Soy nuts & $34.2 \pm 0.4^{\mathrm{c}}$ & $4.2 \pm 0.1^{\mathrm{d}}$ & $71.7 \pm 3.1^{\mathrm{ab}}$ \\
Okara & $20.4 \pm 0.2^{\mathrm{a}}$ & $5.8 \pm 0.1^{\mathrm{bf}}$ & $52.8 \pm 1.3^{\mathrm{c}}$ \\
Low fat soybean flour & $14.6 \pm 0.2^{\mathrm{d}}$ & $6.3 \pm 0.2^{\mathrm{c}}$ & $106.4 \pm 4.4^{\mathrm{d}}$ \\
Textured soy protein & $10.6 \pm 0.1^{\mathrm{e}}$ & $5.3 \pm 0.1^{\mathrm{e}}$ & $96.6 \pm 1.2^{\mathrm{e}}$ \\
Freeze-dried soymilk & $22.3 \pm 0.4^{\mathrm{f}}$ & $5.7 \pm 0.1^{\mathrm{f}}$ & $105.5 \pm 1.3^{\mathrm{d}}$ \\
\hline
\end{tabular}

Results are expressed as mean \pm standard deviation $(n=3)$. Means in the same column with common letters are not significantly different $(P<0.05)$.

\section{RESULTS AND DISCUSSION}

Table 1 presents the proximate composition of both the INIAP 306 soybean variety and the low fat soybean flour obtained from it. The partial elimination of oil through the extrusion increased the protein content of the flour and eliminated more than $90 \%$ of the trypsin inhibitory activity (data not shown). The proximate composition of soy seeds was in accordance with previous results from the literature (Souci et al., 1994).

Isoflavone contents of soy products are presented in Table 2 and representative HPLC chromatograms in Figure 1 (except for that of soy seeds presenting the same content of the raw whole soybean flour). Total isoflavone content varied among different soy varieties and environmental growing conditions (Wang and Murphy, 1994; Lee et al., 2003) and the Ecuadorian variety $(\sim 68 \mathrm{mg}$ per $100 \mathrm{~g})$ was found in the same range of Brazilian varieties, from 57 to $188 \mathrm{mg}$ per $100 \mathrm{~g}$ of soybeans (Genovese et al., 2005) and could be considered low when compared to American (116 to $274 \mathrm{mg} / 100 \mathrm{~g}$ ) and Korean varieties (188 to $949 \mathrm{mg} / 100 \mathrm{~g}$ ) (Wang et al., 2000; Lee et al., 2003).

The soy products represent a way of incorporating isoflavones in the diet of populations that do not consume the grains. Almost all the products analysed presented similar or higher isoflavone 
contents when compared to the seeds (Table 2). Dehulling was shown to be a simple way of increasing the isoflavone content of the flour prepared from raw seeds. This was in accordance with a previous report showing that the hulls, which represented almost $8 \%$ of the seed, had the lowest isoflavone content $(10-20 \mathrm{mg} / 100 \mathrm{~g})$ in relation to the cotyledons $(160-320 \mathrm{mg} / 100 \mathrm{~g})$ and hypocotyls ( 1500 $\mathrm{mg} / 100 \quad \mathrm{~g})$ (Eldridge and Kwolek, 1983). When the oil content was reduced from 24 to $15 \%$ through extrusion, a significant concentration of isoflavones occurred in the low fat flour as the oil was free from isoflavones. Texturization of this flour, however, led to a slight decrease $(\sim 9 \%)$ of the isoflavone content in the textured soy protein (Table 2 ).
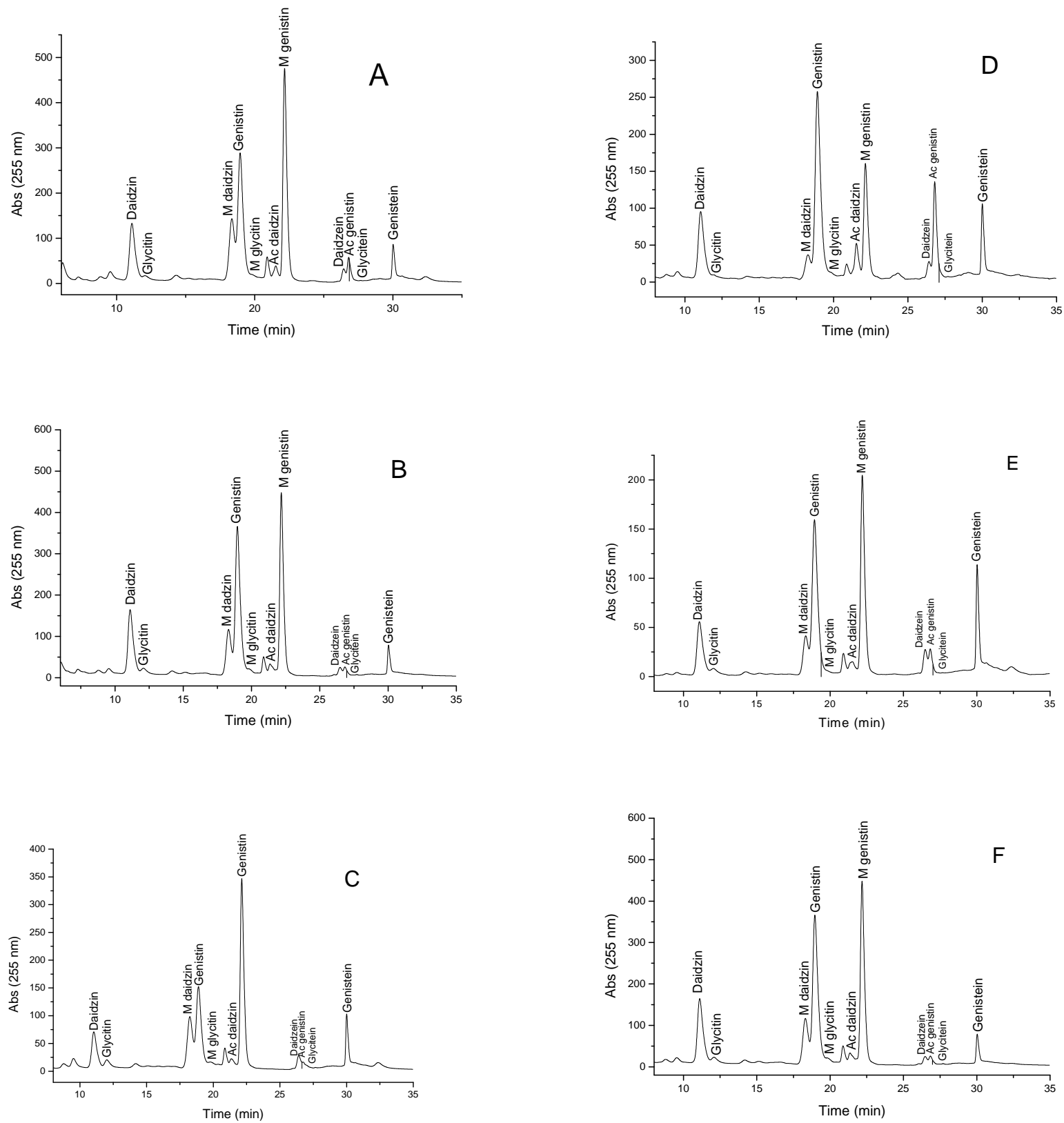

Figure 1 - HPLC chromatograms of isoflavones in (a) low fat soybean flour, (b) soy milk, (c) raw soybeans, (d) soy nuts, (e) Okara and (f) textured soy protein samples. The abbreviations $\mathrm{M}$ and Ac were used for malonyl and acetyl conjugates, respectively. 
Frying was shown not to alter the isoflavone content of the seeds, similar to the results previously reported by Coward et al. (1998). Okara, the water insoluble residue obtained in the production of soy milk, which was normally discarded, also presented a significant isoflavone content, $70 \%$ that of the dehulled flour. Considering that soymilk presented a 94\% moisture content before freeze-drying, the beverage in its form of consumption would have an isoflavone content of $67 \mathrm{mg} / \mathrm{L}$, similar to previous results of Genovese and Lajolo (2002) for commercial soy beverages. The profile of the isoflavones contained in the different soy products can be seen in Table 3 and Figure 2 and showed a predominance of glycosides over aglycones in all products.

Table 3 - Isoflavone profile of soy products produced with INIAP 306 soybeans from Ecuador.

\begin{tabular}{|c|c|c|c|c|}
\hline \multirow{2}{*}{ Soy product } & \multicolumn{4}{|c|}{$\%$} \\
\hline & $\beta$-glycosides & Malonylglycosides & Acetylglycosides & Aglycones \\
\hline Raw whole soybean flour & $33.4 \pm 0.8^{\mathrm{a}}$ & $49.1 \pm 0.5^{\mathrm{a}}$ & $5.4 \pm 0.1^{\mathrm{a}}$ & $12.1 \pm 0.3^{\mathrm{a}}$ \\
\hline Raw dehulled soybean flour & $33.4 \pm 0.8^{\mathrm{a}}$ & $48.4 \pm 0.7^{\mathrm{a}}$ & $6.6 \pm 0.2^{b}$ & $11.7 \pm 0.3^{\mathrm{a}}$ \\
\hline Soy nuts & $46.7 \pm 0.8^{b}$ & $23.7 \pm 0.6^{b}$ & $15.2 \pm 0.2^{\mathrm{c}}$ & $14.3 \pm 0.4^{b}$ \\
\hline Okara & $38.4 \pm 0.4^{\mathrm{c}}$ & $37.0 \pm 0.5^{\mathrm{c}}$ & $6.6 \pm 0.3^{b}$ & $18.0 \pm 0.4^{\mathrm{c}}$ \\
\hline Low fat soybean flour & $37.3 \pm 0.8^{c}$ & $46.8 \pm 0.5^{\mathrm{d}}$ & $7.0 \pm 0.1^{\mathrm{b}}$ & $8.9 \pm 0.5^{\mathrm{d}}$ \\
\hline Textured soy protein & $45.1 \pm 0.3^{\mathrm{d}}$ & $22.8 \pm 0.4^{\mathrm{b}}$ & $20.4 \pm 0.2^{\mathrm{d}}$ & $11.7 \pm 0.2^{\mathrm{a}}$ \\
\hline Freeze-dried soymilk & $48.5 \pm 0.5^{\mathrm{e}}$ & $39.9 \pm 0.4^{\mathrm{e}}$ & $4.2 \pm 0.1^{\mathrm{e}}$ & $7.4 \pm 0.1^{\mathrm{e}}$ \\
\hline
\end{tabular}

Results are expressed as mean \pm standard deviation $(n=3)$. Means in the same column with common letters are not significantly different $(P<0.05)$.

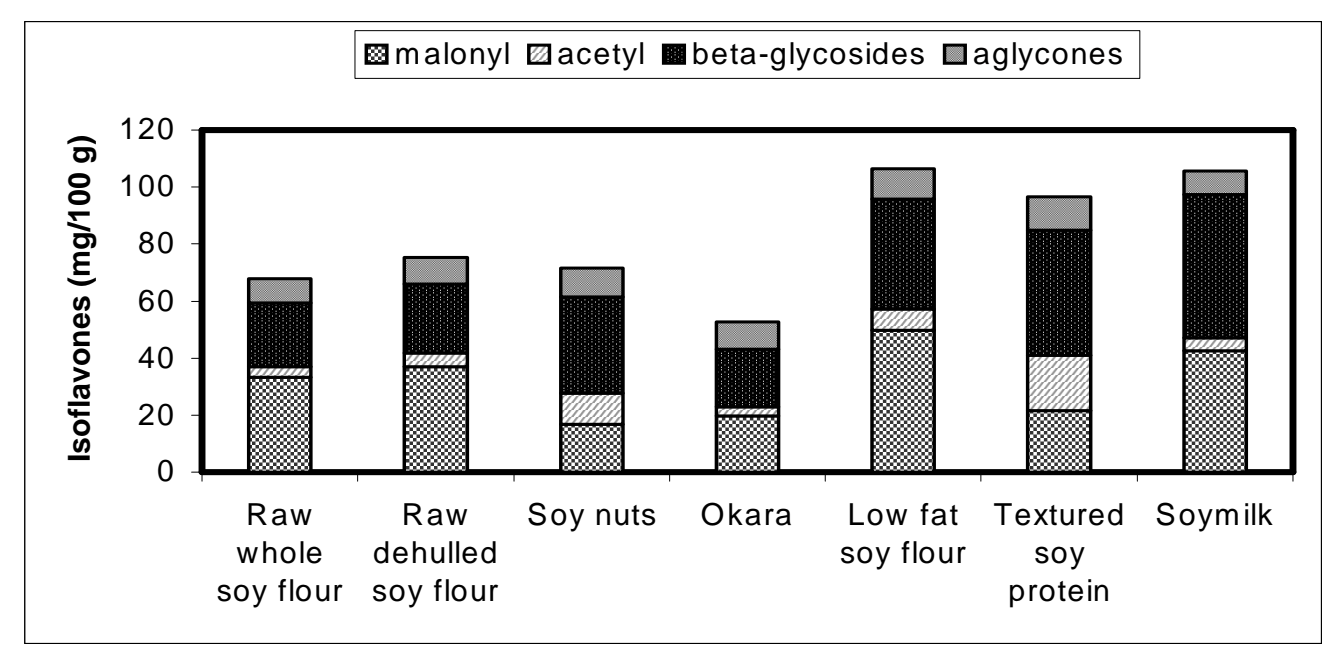

Figure 2 - Total isoflavone content and profile (naturally occurring aglycones, malonyl, acetyl, and $\beta$-glycosides derivatives) of Ecuadorian soy products.

Malonylglycosides were the main form present in the three flours, indicating that extrusion cooking for the obtention of the partially defatted flour was not drastic enough to affect these thermally unstable forms. Frying and texturization, on the other side, led to a significant decrease of malonylglycosides accompanied by an increase of the deesterified $\beta$-glycosides. Textured soy protein also presented an increase in the proportion of acetylglycosides (Table 3). According to Coward et al. (1998), these compounds were more commonly formed during processing involving dry heat, such as toasting of soy flour or extrusion to produce texturized soy protein. Comparing the isoflavone profile of okara and soymilk a decrease was observed in both in the proportion of malonylglycosides in relation to the raw flours, but while in soymilk this was accompanied by an 
increase in $\beta$-glycosides, in okara the proportion of aglycones was higher. This could be explained by differences in water solubility between these forms.

The ratios of malonyldaidzin to daidzin (MD/D) present in the raw flours (1.3 and 1.1) and malonylgenistin to genistin (MG/G) (1.9 and 1.8, for whole and dehulled seeds, respectively) were superior to the values previously reported for Brazilian soybeans [0.4 to 0.7 (MD/D) and 0.6 to 0.9 (MG/G)] (Genovese et al., 2005), confirming that these values would be characteristic for the different genotypes.
Table 4 shows the distribution of isoflavones in terms of total genistein, daidzein and glycitein, which represent the sum of all the forms of each isoflavone (aglycones naturally present, acetyl, malonyl and $\beta$-glycosides) expressed as total aglycones. The products presented similar compositions, with a predominance of genistein followed by daidzein. When comparing soymilk to okara, a preferential solubilization of daidzein derivatives seemed to have occurred. An explanation would be the more hydrophilic nature of daidzein compared to genistein (Coward et al., 1993).

Table 4 - Isoflavone distribution of soy products produced with INIAP 306 soybeans from Ecuador.

\begin{tabular}{|c|c|c|c|}
\hline \multirow{2}{*}{ Soy product } & \multicolumn{3}{|c|}{$\%$ total $*$} \\
\hline & Genistein & Daidzein & Glycitein \\
\hline Raw whole soybean flour & $54.4 \pm 0.4^{\mathrm{a}}$ & $36.7 \pm 0.3^{a}$ & $8.9 \pm 0.2^{a}$ \\
\hline Raw dehulled soybean flour & $57.2 \pm 0.4^{\mathrm{b}}$ & $35.4 \pm 0.3^{b}$ & $7.5 \pm 0.2^{b}$ \\
\hline Soy nuts & $57.8 \pm 0.9^{b}$ & $33.0 \pm 0.5^{\mathrm{c}}$ & $9.2 \pm 0.6^{\mathrm{a}}$ \\
\hline Okara & $58.8 \pm 0.5^{b}$ & $30.5 \pm 0.5^{\mathrm{d}}$ & $10.7 \pm 0.4^{\mathrm{c}}$ \\
\hline Low fat soybean flour & $52.1 \pm 0.4^{\mathrm{c}}$ & $37.6 \pm 0.2^{\mathrm{e}}$ & $10.3 \pm 0.2^{\mathrm{c}}$ \\
\hline Textured soy protein & $51.0 \pm 0.3^{\mathrm{d}}$ & $38.5 \pm 0.3^{f}$ & $10.4 \pm 0.2^{\mathrm{c}}$ \\
\hline Freeze-dried soymilk & $54.1 \pm 0.4^{\mathrm{a}}$ & $37.0 \pm 0.3^{\mathrm{ae}}$ & $8.9 \pm 0.3^{\mathrm{a}}$ \\
\hline
\end{tabular}

*The total percentage of each aglycone represents the sum of the free and conjugated forms, expressed as aglycones, in relation to the total. Results are expressed as mean \pm standard deviation $(n=3)$. Means in the same column with common letters are not significantly different $(P<0.05)$.

\section{CONCLUSIONS}

Soy products prepared from the INIAP 306 variety preserved the isoflavone content of the seed and represented significant isoflavone sources for direct incorporation into the diet and/or preparation of derived products such as bread, flavored soymilks, yogurts, and ice creams. Removal of the seed coat and oil increased isoflavone content of soy products. Processing altered isoflavone profile mainly in relation to a decrease of malonylglycosides and increase of $\beta$ glycosides. In textured soy protein, an increase of acetylglycosides was also observed. Soy products, in general, presented isoflavone composition similar to the seeds with prevalence of genistein followed by daidzein derivatives.

\section{ACKNOWLEDGEMENTS}

The authors acknowledge CYTED (Programa Iberoamericano de Ciencia y Tecnologia para el Desarrollo - CYTED XI. 19. Aplicación de los nuevos ingredientes funcionales em alimentación infantil y para adultos) and FAPESP, for the financial support, and the student Márcia da Silva Pinto (Bolsa de Iniciação Científica FAPESP) for the collaboration with isoflavone analysis.

\section{RESUMO}

Produtos derivados de soja produzidos no Equador, com uma variedade de soja (INIAP 306) desenvolvida e cultivada localmente, tiveram o teor e perfil de isoflavonas determinados através de cromatografia líquida de alta eficiência. Os produtos apresentaram altos conteúdos de isoflavonas, variando de 53 a $106 \mathrm{mg} / 100 \mathrm{~g}$ (base úmida, expresso como agliconas), sendo o menor conteúdo encontrado em okara e o maior na 
farinha parcialmente desengordurada obtida através de extrusão das sementes. Os snacks de soja apresentaram o mesmo conteúdo de isoflavonas que as sementes, mas com quantidades menores de malonilglicosídeos e maiores de $\beta$ glicosídeos desesterificados. Os malonilglicosídeos foram as formas predominantes encontradas nas farinhas e os $\beta$-glicosídeos no leite e na proteína texturizada de soja. Os derivados de genisteína foram os compostos presentes nas maiores proporções em todos os produtos analisados.

\section{REFERENCES}

A.O.A.C. (1995), Official methods of analysis of the association of official analytical chemists. 16. ed. Washington: Association of Official Analytical Chemists, Inc.

Adlercreutz, H. and Mazur, W. (1997), Phytooestrogens and Western diseases. Annals of Medicine, 29, 95-120.

Coward, L.; Smith, M.; Kirk, M. and Barnes, S. (1998), Chemical modification of isoflavones in soyfoods during cooking and processing. American Journal of Clinical Nutrition, 68, 1486S-1491S.

Coward, L.; Barnes, N. C.; Setchell, K. D. R. and Barnes S. (1993), Genistein, daidzein and their $\beta$ glycoside conjugates: antitumor isoflavones in soybean foods from American and Asian diets. Journal of Agricultural and Food Chemistry, 41, 1961-1967.

Dalais, F. S.; Meliala, A.; Wattanapenpaiboon, N.; Frydenberg, M.; Suter, D. A. I.; Thomson, W. K. and Wahlqvist, M. L. (2004), Effects of a diet rich in phytoestrogens on prostate-specific antigen and sex hormones in men diagnosed with prostate cancer. Urology, 64, 510-515.

Eldridge, A. C. and Kwolek, W. F. (1983), Soybean Isoflavones: Effects of Environment and Variety on Composition. Journal of Agricultural and Food Chemistry, 31, 394-396.

Friedman, M. and Brandon, D. L. (2001), Nutritional and health benefits of soy proteins. Journal of Agricultural and Food Chemistry, 49, 1069-1086.

Genovese, M. I. and Lajolo, F. M. (2001), Determinação de isoflavonas em derivados de soja. Ciência e Tecnologia de Alimentos, 21, 86-93.

Genovese, M. I. and Lajolo, F. M. (2002), Isoflavones in soy-based foods consumed in Brazil: levels, distribution, and estimated intake. Journal of Agricultural and Food Chemistry, 50, 5987-5993.
Genovese, M. I.; Hassimotto, N. M. A. and Lajolo, F. M. (2005), Isoflavone profile and antioxidant activity of Brazilian soybean varieties. Food Science and Technology International. [in press].

Lee, S. J.; Ahn, K.; Kim, S. H.; Kim, J. T.; Han, S. J.; Jung, M. Y. and Chung, I. M. (2003), Variation in isoflavone of soybean cultivars with location and storage duration. Journal of Agricultural and Food Chemistry, 51, 3382-3389.

Song, T.; Barua, K.; Buseman, G. and Murphy, P. A. (1998), Soy isoflavone analysis: quality control and a new internal standard. American Journal of Clinical Nutrition, 68, 1474S-1479S.

Souci, S. W.; Fachmann, W. and Kraut, H. (1994), Food composition and nutrition tables. on behalf of the Bundesministerium für Ernährung, Landwirtschaft und Forsten, Bonn; ed. Deutsche Forschungsanstalt für Lebensmittelchemie, Garching B. München. $5^{\text {th }}$ rev. ed. comp. by Heimo Scherz und Friedrich Senser. Medpharm. Boca Raton, FL: CRC Press.

Wang, C.; Sherrard, M.; Pagadala, S.; Wixon, R. and Scott, R. A. (2000), Isoflavone content among maturity group 0 to II soybeans. Journal of the American Oil Chemists' Society, 77, 483-487.

Wang, H. and Murphy, P. A. (1994), Isoflavone composition of American and Japonese soybean in Iowa: Effects of variety, crop year, and location. Journal of Agricultural and Food Chemistry, 42, 1674-167.

Received: May 19, 2005; Revised: October 03, 2005; Accepted: July 11, 2006. 